\title{
Magnetic properties of barium ferrite after milling by high energy milling (hem)
}

\author{
Novrita Idayanti ${ }^{1}$, Tony Kristiantoro ${ }^{1}$, Ardita Septiani ${ }^{1}$ and Ika Kartika $^{2}$ \\ ${ }^{1}$ Research Center for Electronics and Telecommunications, LIPI, Bandung 40135, Indonesia \\ ${ }^{2}$ Research Center for Materials and Metallurgy, LIPI, Banten 15314, Indonesia
}

\begin{abstract}
Magnetic properties of barium ferrite that were mashed by High Energy Milling (HEM) has been characterized. The starting iron oxide powder $\left(\mathrm{Fe}_{2} \mathrm{O}_{3}\right)$ and barium carbonate $\left(\mathrm{BaCO}_{3}\right)$ were prepared by powder metallurgy technique by the stages of mixing, calcining, milling, compacting, and sintering. Weight ratio of $\mathrm{Fe}_{2} \mathrm{O}_{3}: \mathrm{BaCO}_{3}$ was $88.74 \mathrm{wt} \%: 17.52 \mathrm{wt} \%$. Some additives such as calcium oxide $(\mathrm{CaO})$, silicon dioxide $\left(\mathrm{SiO}_{2}\right)$, and polyvinyl alcohol (PVA) were added after calcining process. Milling by HEM was varied at 30,60, 90, 120, and 150 minutes. The ball and container of HEM were made of stainless steel. Characterization micro structure by SEM showed that the milling time affect the grain size of the magnetic powder. The longer of milling time, the grain size was smaller and uniform. Characterization by using magnetic instrument Permagraph showed that the grain size will affect the magnetic properties of barium ferrite. Induction of remanence $(\mathrm{Br})$, coercivity $(\mathrm{HcJ})$, and product energy maximum (BHmax) values increased with increasing milling time. The optimal magnetic properties were obtained at the time of milling 120 minutes with value of $\mathrm{Hc}=1.97 \mathrm{kG}, \mathrm{HcJ}=2.314 \mathrm{kOe}$, and $\mathrm{BHmax}=0.64 \mathrm{MGOe}$.
\end{abstract}

\section{Introduction}

Barium ferrite are known as ceramic magnet and permanent magnet materials which are based on iron oxide $\left(\mathrm{Fe}_{2} \mathrm{O}_{3}\right)$ and barium carbonate $\left(\mathrm{BaCO}_{3}\right)$ [1]. This magnetic has a hexagonal structure, so it is also known as barium hexaferrite. The structure is magnetoplumbite/M-type with the general formula is $\mathrm{MFe}_{12} \mathrm{O}_{19}$ or $\mathrm{MO} .6 \mathrm{Fe}_{2} \mathrm{O}_{3}$, where $\mathrm{M}$ is Barium (Ba), strontium $(\mathrm{Sr})$ or lead $(\mathrm{Pb})$ [2]. Fig. 1. shows crystal structure of M-type barium hexaferrite $\mathrm{BaFe}_{12} \mathrm{O}_{19}$. This structure can be symbolically described as $\mathrm{S} * \mathrm{RSR} * \mathrm{~S} *$ where $\mathrm{R}$ denotes a three-layer block containing two $\mathrm{O} 4$ and one $\mathrm{BaO} 3$ with the composition $\mathrm{Ba}^{2+} \mathrm{Fe}_{6}{ }^{3+} \mathrm{O}_{11}{ }^{2-}$, while $\mathrm{S}$ denotes a two-layer block containing two $\mathrm{O} 4$ with the composition $\mathrm{Fe}_{6}{ }^{3+} \mathrm{O}_{8}{ }^{2-}$. Crystal structure of Mtype barium hexaferrite $\mathrm{BaFe}_{12} \mathrm{O}_{19}$ [3]. The colours of spheres; red, pink, gray, blue and yellow represent iron atoms in $2 \mathrm{a}, 4 \mathrm{fl}, 12 \mathrm{k}, 4 \mathrm{f} 2$, and $2 \mathrm{~b}$ sites respectively. Small green spheres represent oxygen atoms, while larger cyan spheres represent barium atoms [4].

This magnet having high coercivity, high temperature curie, large saturation magnetization, good chemical stability, and corrosion resistive [5]. Use of ferrite magnet materials are one of the most widely in the world although they have less magnetic strength than rare earth magnets. This is because the magnets are cheaper than rear earth magnets [6].

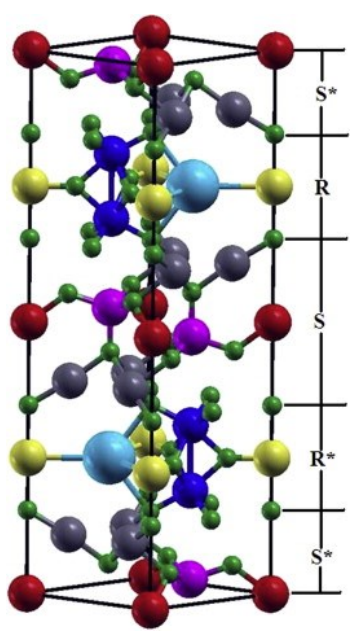

Fig.1. Cell unit of Barium Hexaferrite [4]

There are many methods have been developed for the preparation of barium ferrite to get excellent magnetic properties. YY. Meng, Li Jie, and Zhidong [79] have synthesize barium ferrite by sol gel method by reacting iron nitrate $\left(\mathrm{Fe}\left(\mathrm{NO}_{3}\right)_{3}\right)$, barium nitrate $\left(\mathrm{Ba}\left(\mathrm{NO}_{3}\right)_{2}\right.$, and citric acid were dissolved into distilled water. Co-precipitati on method has been carried out by the researchers by reacting a solution of iron in the ferric chloride with barium chloride in water was poured into an $\mathrm{NaOH} / \mathrm{Na}_{2} \mathrm{CO}_{3}$ alkaline solution [10-11]. $\mathrm{R}$. Nowolsieski [12] and many researchers have been using powder metallurgy for making barium ferrite magnet by

\footnotetext{
* Corresponding author: novr001@lipi.go.id
} 
the reaction of iron oxide and barium carbonate. Among these methods, powder metallurgy process has been considered the best method and the most often use to produce barium ferrite in large scale product. The main advantage of this methodis able to produce a ceramic material that has a high melting point. Many factors in the powder metallurgy process that could affect the properties of magnetic materials such as grain size of the powder after milling. Mechanical treatment ball milling is now recognized as a powerful tool to get fine ferrite powder. In this research refining the grain size of magnetic powders do by High Energy Milling (HEM) with variations of milling time. Magnetic properties after milling observed by Permagraph, micro structure determined by using SEM and the formation of ferrite compounds by XRD.

\section{Experimental details}

A mixture of iron oxide $\left(\mathrm{Fe}_{2} \mathrm{O}_{3}\right)$ and barium carbonate $\left(\mathrm{BaCO}_{3}\right)$ was made base on the composition formula of barium ferrite $\mathrm{BaO}_{3.98} \mathrm{Fe}_{2} \mathrm{O}_{3}$. The calculation chemical composition based on impurities of iron oxide was obtained weight ratio of $\mathrm{Fe}_{2} \mathrm{O}_{3}: \mathrm{BaCO}_{3}$ was $88.74 \mathrm{wt} \%$ : $17.52 \mathrm{wt} \%$. Both materials were mixed and milled by High Energy Milling (HEM) type ultimate gravity with various time $0,30,60,90$, and 120 minutes. 0 minute means that the mixture did not do milling by HEM. Alcohol was added into a mixture as much as $60 \%$ wight of mixture. The next step was calcination process in a furnace (Thermolyne) at temperature $1200^{\circ} \mathrm{C}$ for 3 hours. Calnined powders were characterized by SEM JEOL JCM 6000 USA to determine microstructure and grain size. Analysis of ferrite coumpound after calcination process by using XRD. Some additives such as silicon oxide $\left(\mathrm{SiO}_{2}\right)$, calcium oxide $(\mathrm{CaO})$, and polyvinyl alcohol (PVA) was added approximately $0.75-1.5$ weight $\%$ of calcined powder. The next process, the mixture was milled again by HEM for 60 minutes to obtain a homogeneous powder. After that, the mixture was dried at temperature $100^{\circ} \mathrm{C}$ and sieve with a shieve shaker 400 mesh and the magnet powders were ready to be pressed. The amount of the samples was $2 \mathrm{~g}$, was performed in disk shape with a diameter $11.55 \mathrm{~mm}$ and a thickness $5 \mathrm{~mm}$. The compacting pressure at 5 tons $/ \mathrm{cm}^{2}$ by hydraulic press. The compact samples were placed on an alumina substrate and were sintered at temperature $1250^{\circ} \mathrm{C}$ in air atmosphere with one hour holding time and heating rate was $10^{\circ} \mathrm{C} / \mathrm{min}$. Magnet samples that have been sintered tested by Permagraph Magnet Physik Germany to determine magnetic properties of the samples. Flow chart of the experiment by powder metallurgy process can be seen in Fig. 2 .

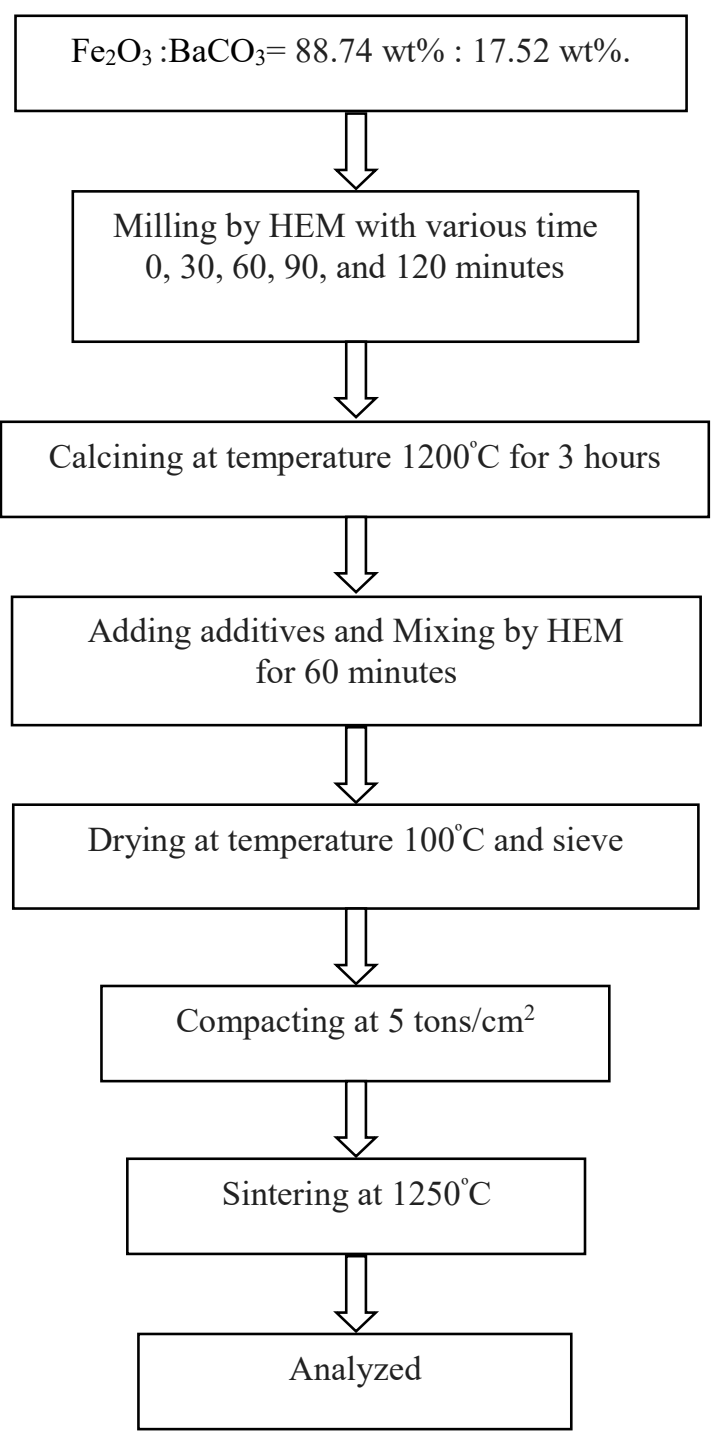

Fig.2. Flow Chart of Process

\section{Results and discussion}

The observation result of microstructure and grain size of samples that milled at 0 minutes until 120 minutes can be seen in Fig. 3 .

SEM analysis shows that milling time can influence microstructure and grain size of the samples. Picture was observed at magnification x1000. In Fig. 3. (a) sample $(0$ minutes) still has large grain size and inhomogeneous. After milling process 30-120 minutes, the grain size become homogenous and smaller. Homogenous distribution of ferrite powder particles after milling is an important factor that could affect the formation of ferrite and the magnetic characteristic [13]. The grain size will affect the magnetic properties because the grain size and grain boundaries will disrupt the movement of momen magnet [14]. The increase in magnetic moment depends on the structure of the grain boundary and grain size [15]. It will be proved after the measurement of magnetic properties. 


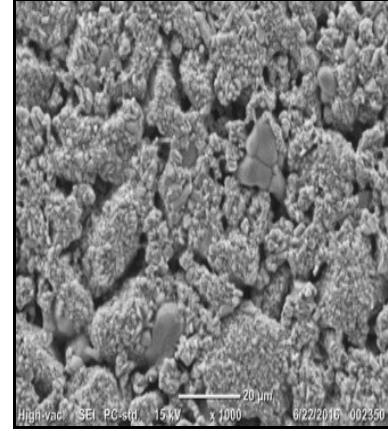

(a)

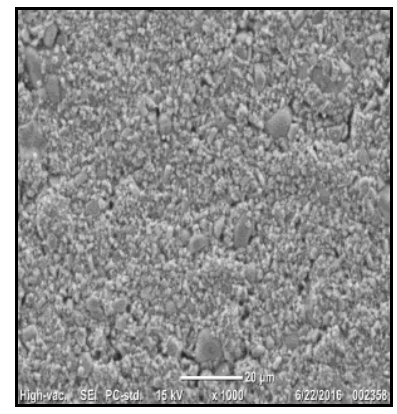

(c)

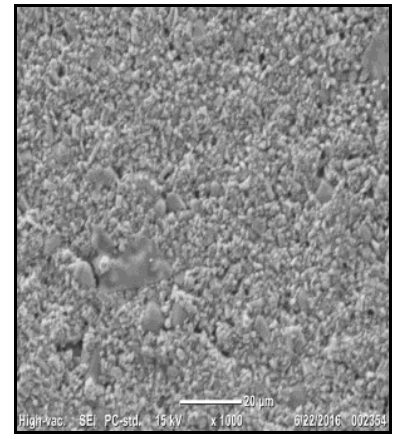

(b)

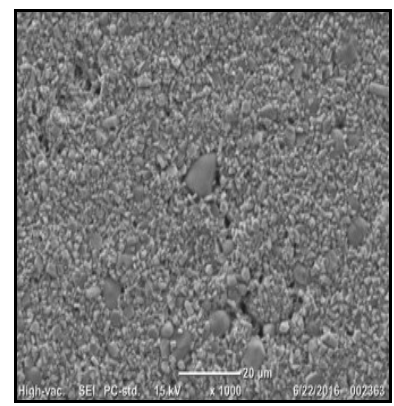

(d)

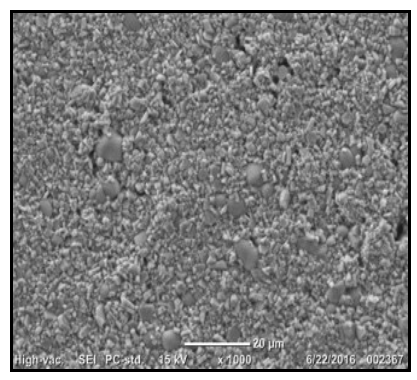

(e)

Fig.3. Microstructure and Grain Size of Samples

In Fig. 4. powder XRD patterns of calcine powder with different milling times $(0-120$ minutes $)$ are shown. Sharp peak indicating the high crystallinity of the samples. The blunt peak showed crystalline sample is not perfect. Samples were milled at the times $0-60$ minutes has not had sharp peaks. Sharp curve has shown after milling 90 minutes. The compound formed is barium ferrite $\left(\mathrm{BaFe}_{12} \mathrm{O}_{19}\right)$, still there are hematite $\left(\mathrm{Fe}_{2} \mathrm{O}_{3}\right)$, and magnetite $\left(\mathrm{Fe}_{3} \mathrm{O}_{4}\right)$ that unfinished reacted with barium carbonate $\left(\mathrm{BaCO}_{3}\right)$. For the sample milled 120 minutes, the formation of barium ferrite compound is better. These effect indicate that milling process by HEM on ferrite powder will influence the formation of barium ferrite.

XRD characterization results of samples that have been sintered can be seen in Fig. 5. The curve of sintered powder are sharper than calcined powder. The coumpound is formed almost entirely is barium ferrite. $\mathrm{Fe}_{3} \mathrm{O}_{4}$ has reacted become $\mathrm{BaFe}_{12} \mathrm{O}_{19}$, while $\mathrm{Fe}_{2} \mathrm{O}_{3}$ compound is still there.

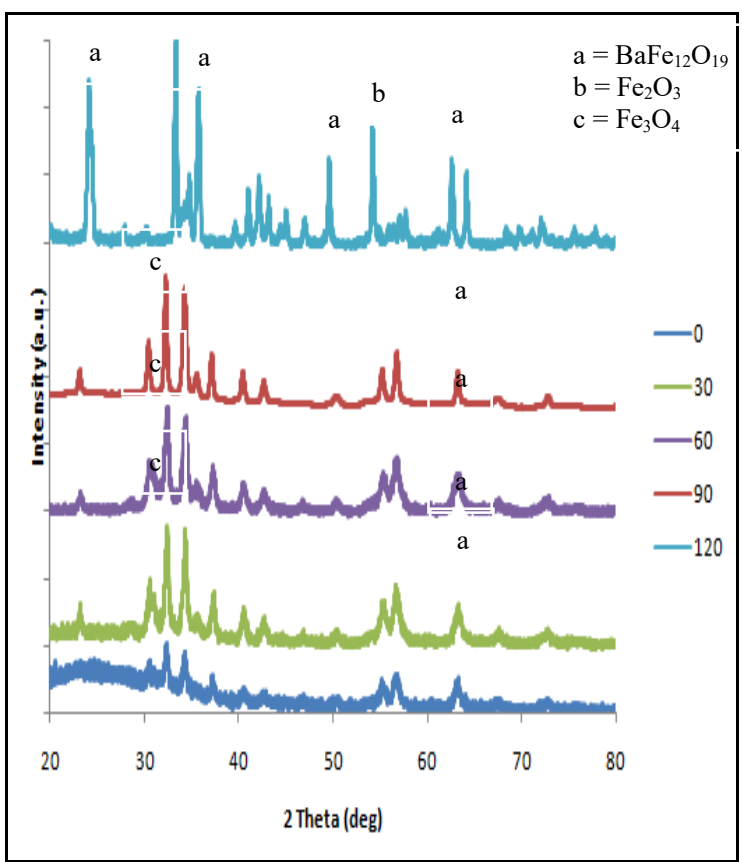

Fig.4. Diffraction Patterns of Calcined Powder

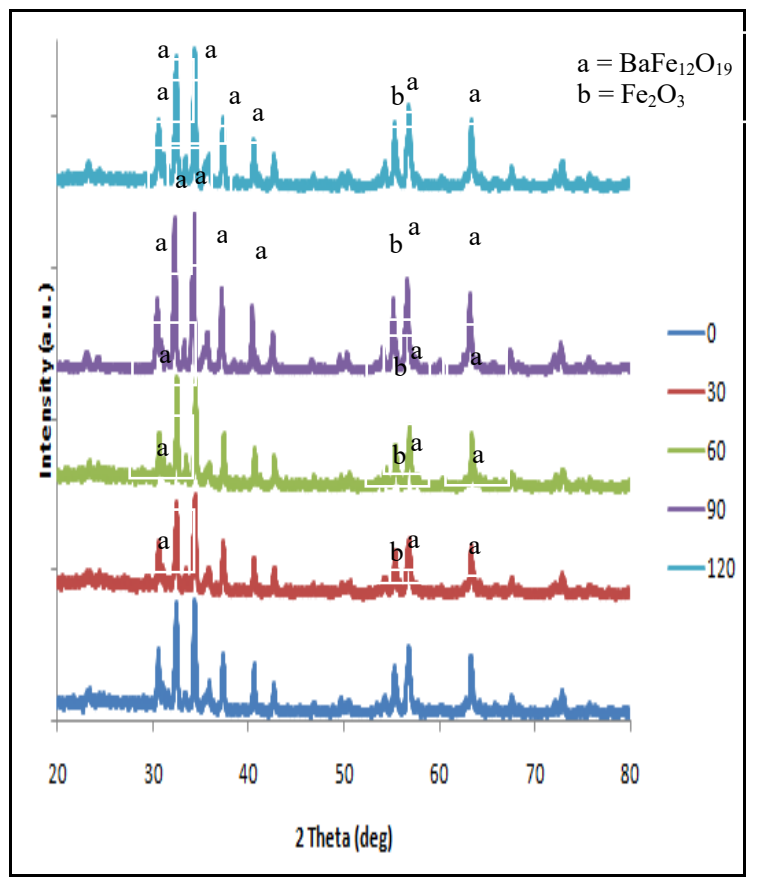

Fig.5. Diffraction Patterns of Sintered Powder

On Fig. 4. And Fig. 5. can be seen that after the sintering process the formation of barium ferrite magnetic material more complete and perfect. It can be shown from number of compound $\mathrm{BaFe}_{12} \mathrm{O}_{19}$ that appear on the XRD curve of

Fig.6 shows hysteresis loop of barium ferrite after milling $0,30,60,90$, and 120 minutes. The powder were observed after sintering $1250^{\circ} \mathrm{C}$ by using Permagraph. 


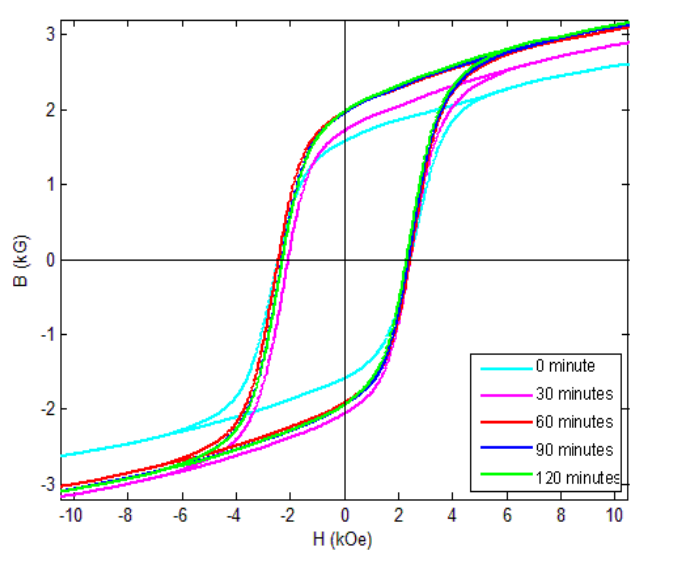

Fig.6. Hysteresis Curve of Samples

Fig. 6. Hysteresis loops for milled samples showing the effect of milling process on the shape of the demagnetization curve. At longer milling times, saturation magnetization keeps nearly constant, while that induction of remanence $(\mathrm{Br})$ increase. Increasing in coercivity $(\mathrm{HcJ})$ is associated to high density of internal stresses. Decreasing of product energy maximum (BHmax) as a consequence of the grain size is below of the exchange correlation length. High values of coercivity are related to particles are significantly smaller than the single-domain size. Sample which has the best magnetic characteristics is sample milled 120 minutes with the value of $\mathrm{Br}=1.97 \mathrm{kG}, \mathrm{HcJ}=2.314$ $\mathrm{kOe}, \mathrm{BHmax}=0.64 \mathrm{MGOe}$, and density $5.01 \mathrm{~g} / \mathrm{cm}^{3}$. The magnetic properties of samples obtained from hysteresis curve of barium ferrite is shown in Table 1 below.

Table 1. The influence of milling time on the magnetic properties

\begin{tabular}{|l|c|c|c|c|c|}
\hline \multirow{2}{*}{$\begin{array}{c}\text { Magnetic } \\
\text { Propertie } \\
\begin{array}{c}\text { s and } \\
\text { Density }\end{array}\end{array}$} & \multicolumn{5}{|c|}{$\begin{array}{c}\text { Variations of milling time } \\
\text { (minutes) }\end{array}$} \\
\cline { 2 - 6 } & $\mathbf{0}$ & $\mathbf{3 0}$ & $\mathbf{6 0}$ & $\mathbf{9 0}$ & $\mathbf{1 2 0}$ \\
\hline $\mathrm{Br}(\mathrm{kG})$ & 1.57 & 1.88 & 1.94 & 1.95 & 1.97 \\
\hline $\mathrm{HcJ}(\mathrm{kOe})$ & 2.453 & 2.244 & 2.419 & 2.339 & 2.314 \\
\hline $\begin{array}{l}\mathrm{BHmax} \\
(\mathrm{MGOe})\end{array}$ & 0.50 & 0.70 & 0.74 & 0.74 & 0.64 \\
\hline$\rho\left(\mathrm{g} / \mathrm{cm}^{3}\right)$ & 4.23 & 4.80 & 4.85 & 4.88 & 5.01 \\
\hline
\end{tabular}

K. Sadhana [16] has done research to observe effect of grain size on the structural and magnetic properties of nanocrystalline $\mathrm{Al}_{3} \mathrm{Fe}_{5} \mathrm{O}_{12}$. The grain size can influence coercive field (Hc). It was observed that $\mathrm{Hc}$ increases with an increase of $\mathrm{D}$ and further increase until $\mathrm{Dc}, \mathrm{Hc}$ decreases. The boundary between single domain and multidomain particle is given by critical diameter of the particle (Dc).

\section{Conclusion}

Barium ferrite was sucessfully characterized after milling by HEM. The milling time influences of grain size, formation of compound, and magnetic properties of barium ferrite. The following conclusions are :

- The longer milling times will make increasingly refined powder.

- Density of ferrite powder increased.

- Increas in density can affect magnetic properties

- The formation of barium ferrite most perfect is the ferrite powder the milling time of 120 minutes.

- Magnetic properties is better because fine and homogenous powder can align magnetic moment easily.

In the next research, addition of milling time should be added to determine the influences.

The authors greatly to thank you for the financial support provided by LIPI under the Superior Research Program (Riset Unggulan) 2016.

\section{References}

1. R. Nowosielski, R. Babilas, G. Derce, L. Pajak, J. Wrona, Structure and properties of barium ferrite powder prepared by milling and annealing, International scientific J. published monthly as the organ of the committee of materials sciences of the polish academy of sciences, vol. 28, issue 12, P 736-742 (2007)

2. D. Bahadur, Influence of fuel ratios on auto combustion synthesis of barium ferrite nano particles, J. Chemical Science, Vol. 118, 1, P 15-21 (2006)

3. Z. Somogyvan, E. Syab, K. Krezhov, L.F. Kiss, D. Kaptas, I. Vincze, E. Beregi, F. Bouree, J. of magnetism and magnetic materials, Vol. 304, issue 2, P e775-e777 (2014)

4. A. Moitra, S. Kim, S.G. Kim, S.C. Erwin, Y.K. Hong, J. Park, Computational Condensed Matter, Vol. 1, P 45-50 (2014)

5. R. Nowosielski, R. Babilas, J. Wrona, Microstructure and magnetic properties of commercial barium ferrite powder, $J$. of Achievements in Materials and Manufacturing Engineering, vol. 20, issue 1-2 (2007)

6. M.Y. Jassem, Preparation of barium ferrite $\mathrm{BaFe}_{12} \mathrm{O}_{19}$ and the study of the effect of fast neutrons on its magnetic and dielectrical properties, College of Basic Education Researchers J. University of Mosul/ College of Basic Education, Vol.11 No.1 (2011)

7. Y.Y. Menga , M.H. He a , Q. Zeng a, D.L. Jiao a, S. Shukla b , R.V. Ramanujan b , Z.W. Liu, Synthesis of barium ferrite ultrafine powders by a sol-gel combustion method using glycine gels, J. of Alloys and Compounds, 583, P 220-22 (2014)

8. Li Jie, Zhang Huai-Wu, Li Yuan-Xun, Liu Ying-Li, and Ma Yan-Bing, The structural and magnetic properties of barium ferrite powders prepared by the sol gel method, Chin. Phys. B ,Chinese Physical Society and IOP Publishing Ltd, Vol. 21, No. 1 (2012)

9. H. Yaoming Z., Ze WU, Xianyou Z., Synthesis of hexagonal barium ferrite nanoparticle by sol-gel method, Rare Metals Elsevier,Vol. 25, Issue 6, Supplement 1, P 605-608 (2006) 
10. S.R.Janasi, M.Emura, F.J.G.Landgraf, D.Rodrigues, the effects of synthesis variables on the magnetic properties of coprecipitated barium ferrite powders, J. of Magnetism and Magnetic Materials, 238, P 168-172 (2002)

11. Y. Atassi, I. Seyd Darwish, M. Tally, Preparation and Characterization of Nano-particle Substituted Barium Hexaferrite, Chem. Physic Cornell Univ. library (2014)

12. R. Nowosielski a, R. Babilas a, G. Dercz b, L. Pająk, Microstructure of polymer composite with barium ferrite powde, $J$. of Achievements in Materials and Manufacturing Engineering, Vol. 31, Issue 2, P 269-274 (2008)

13. W. Kaszuwara, A.Witowski, M. Leonowicz, P. Pawlik, J. Paszula, effect of milling medium on the structure and magnetic properties of mechanically alloyed barium ferrite, Rev. Adv. Mater. Sci. P 497-500 (2008)

14. I.R. Haris, I.P. Jones, Grain Boundarie: their character, characterization and influence on properties, Maney Publishing (2001)

15. Dr. S. Ii S, discovery of increase in magnetic moment at grain boundaries, Scripta Materials, National Institute for Materials Science Kumamoto University (2013)

16. K. Sadhana, S.E. Naina Vinodini, R.Sandhya and K. Praveena, effect of grain size on the structural and magnetic properties of nanocrystalline $\mathrm{Al}_{3} \mathrm{Fe}_{5} \mathrm{O}_{12}$ by aqueous coprecipitation method, Adv. Mater. Lett. P 99$107(2015)$ 